Journal of Zhejiang University-SCIENCE A (Applied Physics \& Engineering)

ISSN 1673-565X (Print); ISSN 1862-1775 (Online)

www.zju.edu.cn/jzus; www.springerlink.com

E-mail: jzus@zju.edu.cn

\title{
Erratum:
}

\section{Erratum to: Emission characteristics of hazardous components in municipal solid waste incinerator residual ash}

\author{
Xiao-dong LI $\mathrm{LI}^{\dagger}$ Y Yong REN, Sha-sha JI, Xia-li HOU, Tong CHEN, Sheng-yong LU, Jian-hua YAN \\ (State Key Laboratory of Clean Energy Utilization, Zhejiang University, Hangzhou 310027, China) \\ ${ }^{\dagger}$ E-mail: lixd@zju.edu.cn
}

doi: $10.1631 /$ jzus.A14e0142

Erratum to: J Zhejiang Univ-Sci A (Appl Phys \& Eng) 2015 16(4):316-325 doi:10.1631/jzus.A1400142

The original version of this article unfortunately contained some mistakes.

In p.318, the column of "Pore size (nm)" in Table 2 was incorrect, and the correct unit is $\AA$ instead of nm.

In p.322, the numerical values of metal concentrations in the test were incorrectly used, because one batch of the detection values was incorrectly used instead of the average values.

The sentence " $\mathrm{Cu}$, as the indicator of toxic heavy metals, ranged from 89 to $1417 \mathrm{mg} / \mathrm{kg}$ in fly ash and 167 to $469 \mathrm{mg} / \mathrm{kg}$ in bottom ash." should be " $\mathrm{Cu}$, as the indicator of toxic heavy metals, ranged from 94 to $1501 \mathrm{mg} / \mathrm{kg}$ in fly ash and 164 to $461 \mathrm{mg} / \mathrm{kg}$ in bottom ash."

The sentence "Non-toxic heavy metals occupied the major proportions in total heavy metal in residual ash with 841 to $7376 \mathrm{mg} / \mathrm{kg} \mathrm{Ni}$ and 1250 to $6650 \mathrm{mg} / \mathrm{kg} \mathrm{Zn}$, much higher than Mn and Sn." should be "Non-toxic heavy metals occupied the major proportions in total heavy metals in residual ash with 327 to $7201 \mathrm{mg} / \mathrm{kg} \mathrm{Ni}$ and 687 to $8007 \mathrm{mg} / \mathrm{kg} \mathrm{Zn}$, much higher than Mn and Sn."

The sentence "The concentrations of $\mathrm{Al}$ ranged from 44469 to $108540 \mathrm{mg} / \mathrm{kg}$ and that of $\mathrm{Fe}$ ranged from 4020 to $49336 \mathrm{mg} / \mathrm{kg}$." should be "The concentration of Al ranged from 20322 to $106635 \mathrm{mg} / \mathrm{kg}$ and that of Fe ranged from 4075 to $50471 \mathrm{mg} / \mathrm{kg}$."

In p.322, the description about $\mathrm{Hg}$ should be removed.

The online version of the original article can be found at http://dx.doi.org/10.1631/jzus.A1400142

(C) Zhejiang University and Springer-Verlag Berlin Heidelberg 2015 